\title{
EFFECT OF ORGANIC AND INORGANIC FERTILIZERS, OR THEIR COMBINATIONS ON YIELD AND QUALITY COMPONENTS OF OIL SEED SUNFLOWER IN A SEMI-ARID ENVIRONMENT
}

\author{
Firat SEFAOGLU ${ }^{1}$, Hatice OZTURK ${ }^{2}$,Erdogan OZTURK ${ }^{2}$, Murat SEZEK ${ }^{2}$, Zehra TOKTAY ${ }^{2}$, Taskin \\ POLAT ${ }^{2}$ \\ ${ }^{1}$ Kastamonu University, Faculty of Engineering and Architecture, Department of Genetic and \\ Bioengineering, Kastamonu, TURKEY \\ ${ }^{2}$ Atatürk University, Faculty of Agriculture, Department of Field Crops, Erzurum, TURKEY \\ *Corresponding author: fsefaoglu@kastamonu.edu.tr
}

Received: 27.01.2021

\begin{abstract}
Producers in semi-arid and highland regions have difficulty in increasing diversity in crop rotations due to unfavorable conditions imposed by cool temperatures, inadequate rainfall, and shorter growing periods. In such conditions, some cultural practices that increase productivity such as fertilization appear as a promising alternative. Fertilization and the form of fertilizer have a substantial influence on sunflower (Helianthus annuus L.) seed yield and quality. The objective of this study was to determine the responses of the oilseed sunflower to organic (vermicompost and leonardite) and inorganic (nitrogen and phosphorus) fertilizers, or their combinations in a semiarid conditions. To this end, the field research was carried out in 2017 and 2018 in Erzurum, Eastern Anatolia, Turkey. In this study, it was found that the organic and inorganic fertilizers alone and their combinations significantly affected all the plant parameters. The highest seed yield $\left(4854 \mathrm{~kg} \mathrm{ha}^{-1}\right) \mathrm{and}^{-1}$ oil yield ( $2114 \mathrm{~kg} \mathrm{ha}^{-1}$ ) were obtained from the combined use of nitrogen and vermicompost. Moreover, the use

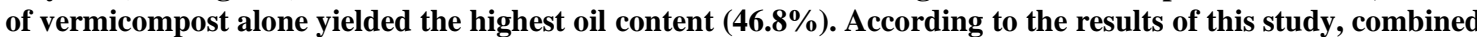
applications of organic (vermicompost) and inorganic (nitrogen) fertilizers had the highest yield and agronomic characteristics in oilseed sunflower production; so, these applications can be recommended for the similar ecological conditions, that is, short growing season and high altitude.
\end{abstract}

Keywords: Helianthus annuus L., leonardite, nitrogen, phosphours, verimcompost, yield components.

\section{INTRODUCTION}

Economic production is possible only in a limited number of plants in arid and semi-arid regions due to irregular and insufficient precipitation (Flagella et al., 2002; Reddy et al., 2003). Sunflower, one of the most important crops that can be grown under these conditions, has served as a "lifesaver" for the production of vegetable oil in Turkey and in the world and prevented the oil deficit from growing further. Obtaining a high yield per unit area is based on the cultivation of varieties with high yield potential under suitable climatic conditions using appropriate agronomic practices. Adequate and balanced amounts of nutrients must be available for optimal plant growth. Fertilizers, which are important for oilseed plants, make important contributions to the entire stage of cultivation, from sowing seeds to ripening and harvesting. Sunflower takes more nutrients from the soil than many cultivated plants, and this increases the importance of fertilization. Therefore, the relationships between fertilizer and product should be determined very well. Previous studies have revealed that a proper fertilization significantly affects the seed and oil yield of sunflower (Makinde et al., 2010; Olaniyi et al., 2010).

The yield has been increased by using fertilizers for years, and these fertilizers have caused soil fatigue, desertification, and even a decrease in vitality after years. Therefore, producers started to use organic fertilizers to improve the physical and chemical structure of soils and to facilitate the nutrient intake. Considering the increasing demand for organic agriculture, it is obvious that the use of organic fertilizers should be extended in order to reduce the environmental pollution and ensure sustainable soils (Khodaei-Joghan et al., 2018) as well as reducing the use of inorganic (nitrogen and phosphorus) fertilizers. In addition to some organic materials used in agriculture such as humic and fulvic acid, leonardite and compost; fertilizers like vermicompost, which contains different types of microorganisms, algae extracts, and enzymes, are more effective in plant growth and development compared to farmyard manure (Atiyeh et al., 2000). Because vermicompost improves the physical structure of the soil and increases the amount of organic carbon, N, P, Zn, K, 
$\mathrm{Ca}$, and $\mathrm{Mn}$ in it (Azarmi et al., 2008). Leonardite is also a natural organic material at the level of coal, which has an organic matter content of up to $75 \%$ and contains a high level of humic acids and orbea carbon. It is an important source of humic and fulvic acid. Moreover, in addition to providing organic matter, leonardite contributes positively to the physical and chemical quality of the soil by providing humic and fulvic acid. It can also be used in combination with natural or chemical fertilizers in agricultural applications, as well as being used alone in various forms.

Some soils where sunflower is cultivated do not contain nutrients enough for plant growth and high yield of grain and oil. In order to compensate this disadvantage, a nutritional supplement should be provided by applying organomineral and inorganic compound fertilizers. However, if inorganic fertilizers are used continuously, they may cause an imbalance in the $\mathrm{pH}$ level of the nutrients and soil. On the other hand, the use of inorganic or organic fertilizers alone does not increase the plant productivity to the expected level. It was reported that an important interaction existed between the application of organic fertilizers and the efficiency of inorganic fertilizers (Gorttappeh et al., 2000; El-Ghamry et al., 2009) and they increased the benefits of most nutrients (nitrogen, phosphorus, and sulfur, etc.) (Waclawowicz et al., 2006). Hussain et al. (2010) found a higher plant height and dry matter yield when inorganic fertilizers were used alone and in combination with organic fertilizers. On the other hand, Kimana et al. (2018) reported that organic and inorganic fertilizers had a positive effect on the oil content of sunflower in general, and applying organic fertilizers increased the oil content. The use of vermicompost alone or in combination with other organic or mineral fertilizers was found to be effective in increasing the growth and yield of various plants (Singh et al., 2011; Javaad and Panwar, 2013).

On the other hand, the highest grain yield (1878 - 2160 $\left.\mathrm{kg} \mathrm{ha}^{-1}\right)$ and 1000 -grain weight $(56.67 \mathrm{~g})$ were reported to be obtained by using vermicompost in combination with inorganic fertilizers such as nitrogen (Sharma et al., 2008; Soleymani et al., 2016). In their study, Buriro et al. (2015) reported that the highest plant height, stem diameter, head diameter, grain yield, and oil content were obtained in sunflower by the combinations of organic and inorganic fertilizers.

Fertilizers, which are important inputs of production, are increasingly being used because they contain the chemical compounds that are a must to obtain more products in the agricultural production process. Despite their increased use, a sufficient yield increase cannot be achieved. Applying fertilization indiscriminately in order to increase yield causes deterioration in soil structure, decrease in soil fertility by creating an imbalance of plant nutrients in the soil, environmental pollution, increase in costs due to abnormal increases in fertilizer prices, and deterioration of product quality. Therefore, there is a need for identifying the fertilizer types required to increase the yield in areas where sunflower is grown and testing their performance under different environmental conditions. To meet this need, in this study it was attempted to determine the effects of various chemical fertilizers (nitrogen and phosphorus) and organic fertilizers such as leonardite and vermicompost on yield and quality of oil seed sunflower.

\section{MATERIALS AND METHODS}

Field experiments were carried out at the Plant Production Application and Research Center (39 $97^{\circ} \mathrm{N}$ and $41^{\circ} 67^{\prime} \mathrm{E} ; 1663 \mathrm{~m}$ above sea level), Atatürk University in Erzurum/Turkey in 2017 and 2018. The soil of two experimental sites was a silty loam (fine, mixed, mesic ustorthents) with pH 7.6, $0.77 \%$ organic matter, $63 \mathrm{~kg} \mathrm{ha}^{-1}$ available $\mathrm{P}$ and $2300 \mathrm{~kg} \mathrm{ha}^{-1}$ available $\mathrm{K}$ in 2017 and $\mathrm{pH}$ $7.3,0.74 \%$ organic matter, $70 \mathrm{~kg} \mathrm{ha}^{-1}$ available $\mathrm{P}$ and 2335 $\mathrm{kg} \mathrm{ha}^{-1}$ available $\mathrm{K}$ in 2018. Data for temperature, rainfall, and relative humidity during the crop-growing period is presented in Figure 1.

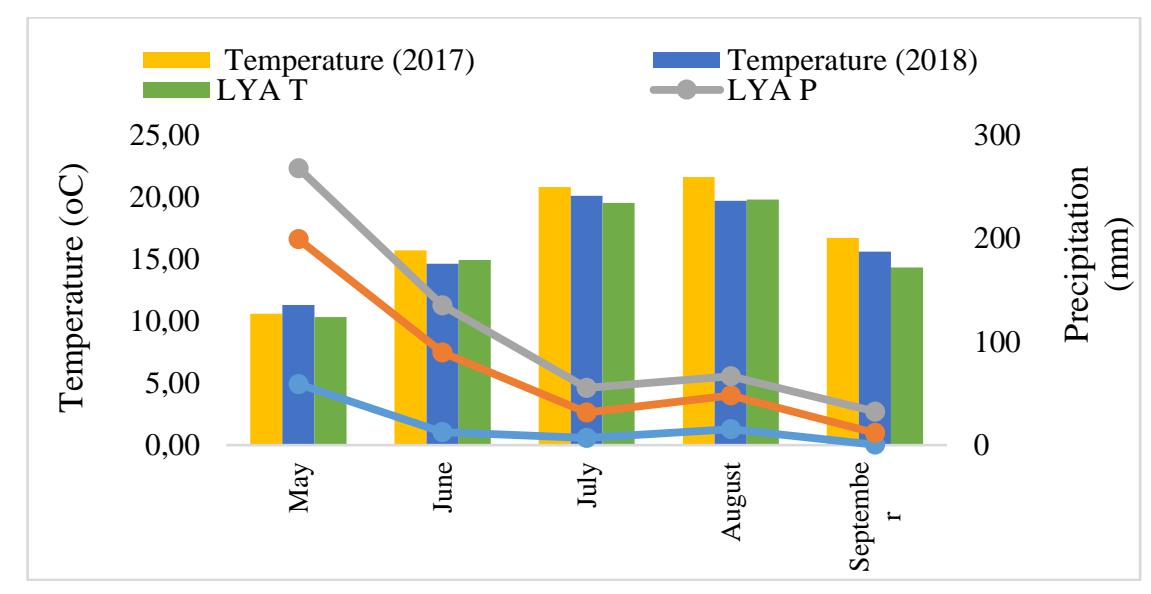

Figure 1. Some important climate data for the experimental sites in the long term and 2017-2018

Air temperatures during the two growing seasons were higher than the long-term mean. Temperatures in April to
September were slightly above normal with an average of $15.8{ }^{\circ} \mathrm{C}$ in 2017 and 2018. There was a considerable 
variability in rainfall amounts and distribution from year to year. In 2017, rainfall was below the long-term average; but in 2018, rainfall was higher than the long term average. The average rainfall for $2018(285.9 \mathrm{~mm})$ was higher than that for 2017 (94 mm).

In both experiments, the previous crops planted on the plots in 2017 and 2018 were barley (Hordeum vulgare L.) and wheat (Triticum vulgare L.) The plot areas were moldboard plowed in the fall and cultivated twice in the spring. Medium early Sirena was used as the oil sunflower cultivar in this study.

This study was designed in randomized blocks with 3 replications and carried out in 2017 and 2018 to examine the effect of nitrogen $(\mathrm{N})$ and phosphorus $(\mathrm{P})$ inorganic fertilizers and leonardite (L) and vermicompost (V) on Sirena oil sunflower. The inorganic and organic fertilizers were used individually and in dual combinations in each block (N, P, L, V, NP, NL, NV, PL, PV, LV, and control (C)). $100 \mathrm{~kg}$ per hectare of ammonium sulphate $(21 \% \mathrm{~N})$ and $80 \mathrm{~kg}$ per hectare of triple super phosphate $(45 \% \mathrm{P})$ were used as nitrogen and phosphorus fertilizers, respectively. $1000 \mathrm{~kg}$ per hectare of leonardite (organic matter $56.7 \%, \mathrm{pH} 7.9$, humidity $25.8 \%$, and total acid (humic-fulvic) $48.8 \%$ ) and $1500 \mathrm{~kg}$ per hectare of vermicompost (organic matter 65.5\%, $\mathrm{pH} 8.1$, total nitrogen $1 \%$, 1 , water-soluble potassium $1.5 \%$, and total phosphorus $0.7 \%$ ) were applied. All the fertilizers were added uniformly to the seed bed before planting in both years. Sowing was carried out manually on May 4, 2017 and May 6, 2018.

The sunflower cultivars were sown $35 \mathrm{~cm}$ apart in rows that were $70 \mathrm{~cm}$ apart. Three seeds were sown in each hill, and then the plots were hand-thinned to one plant per hill when the plants were at the four- to six-leaf stage. Weeds were controlled both mechanically and by hand using a hoe. All the plots were furrow irrigated regularly to avoid drought stress. Each irrigation brought the soil moisture back to near field capacity. Water was applied uniformly to all plots. On September 23, 2017 and September 26, 2018, the sunflower plants were hand-harvested at the physiological maturation stage when the back of the sunflower head turned from green to yellow and the bracts were turning brown.

All the data was analyzed using SPSS package (SPSS, Version 20.0, SPSS Inc, Chicago, IL, USA). When the Ftest indicated a statistical significance at the level of $\mathrm{P}=0.05$, the protected least significant difference (Protected DUNCAN) was used to separate the means (Steel and Torrie, 1980).

\section{RESULTS AND DISCUSSION}

In general, all the measured traits, except plant height, differed between years. So, year affected the head diameter, 1000-grain weight, oil yield, oil and protein content $(\mathrm{p}<0.01)$, and seed yield $(\mathrm{p}<0.05)$. According to the results obtained from this study, the application of organic and chemical fertilizers alone, or in combination created a significant difference in all the measured traits $(\mathrm{p}<0.01)$, except for protein content $(\mathrm{p}<0.05)$. Also, there were very significant $(\mathrm{P}<0.01,0.05)$ fertilizer application $\times$ year interactions for other parameters investigated, except head diameter, 1000-grain weight, and seed and oil yield (Table 1).

\section{Plant height}

Considering the average of all factors used in the study, the plant height was found to be higher in $2018(182.5 \mathrm{~cm})$ than in $2017(180.2 \mathrm{~cm})$, possibly due to changing climatic factors (Figure 1). Montemurro et al. (2007) reported that sufficient rainfall during growing season increased the initial vegetative growth in sunflowers. The application of organic and inorganic fertilizers alone and in combination created differences in the plant height, and the plant height was found to higher in the plants with fertilizer compared to the plants without fertilizer (control). This increase was $9.2 \%$ in inorganic fertilizers, $4.9 \%$ in organic fertilizers, and $6.7 \%$ in the combinations of organic and inorganic fertilizers. The lowest plant height was obtained from the control (no fertilizer), whereas the highest plant height was obtained from the application of $\mathrm{N}(198.0 \mathrm{~cm})$ alone, followed by nitrogen + leonardite $(188.1 \mathrm{~cm})$, phosphorus alone $(174.3 \mathrm{~cm})$, and leonardite alone $(173.4 \mathrm{~cm})$.

Plant height is a vegetative growth index. Considering the fact that nitrogen is one of the building blocks of proteins, the presence of nitrogen plays a key role in plant and cell growth. It has been shown that nitrogenous fertilizers increase the growth rate and plant height in sunflowers (Wabekwa et al., 2012; Seghatoleslami et al., 2012; Day and Kolsaric1, 2014). The combinations of organic and inorganic fertilizers also increased the plant height. Similarly, Hussain and Thomas (2010) also reported that organic and inorganic fertilizers increased the plant height in sunflowers.

\section{Head diameter}

Head diameter is one of the important yield components in sunflowers. It is significantly affected by the ecological factors such as temperature, soil moisture and fertility, and the agricultural practices such as fertilization. The average head diameters of the sunflower plants were found to be 20.1 and $20.8 \mathrm{~cm}$ in 2017 and 2018, respectively. Rainfall and temperature were appropriate in 2018 (Figure 1), especially during the flowering period, and this might have increased the head diameter. Uslu et al. (2002) also reported that low temperature and humidity during the flowering, temperature and drought during the stem elongation caused differences in head diameter. 
Table 1. Mean plant height, head diameter, 1000-grain weight, seed yield, seed oil content, oil yield and protein content of oilseed sunflower during the 2017 and 2018 growing seasons in Erzurum, Turkey, and the results of analysis of variance

\begin{tabular}{|c|c|c|c|c|c|c|c|c|}
\hline Treatments & & $\begin{array}{c}\text { Plant } \\
\text { height } \\
(\mathbf{c m})\end{array}$ & $\begin{array}{c}\text { Head } \\
\text { Diameter } \\
(\mathbf{c m})\end{array}$ & $\begin{array}{c}\text { 1000- } \\
\text { Grain } \\
\text { Weight } \\
\text { (g) }\end{array}$ & $\begin{array}{c}\text { Seed } \\
\text { yield } \\
\left(\mathbf{k g ~ h a}^{-1}\right)\end{array}$ & $\begin{array}{c}\text { Oil } \\
\text { content } \\
(\%)\end{array}$ & $\begin{array}{c}\text { Oil } \\
\text { yield } \\
\left(\mathbf{k g ~ h a}^{-1}\right)\end{array}$ & $\begin{array}{c}\text { Protein } \\
\text { content } \\
(\%)\end{array}$ \\
\hline \multicolumn{9}{|l|}{$\begin{array}{l}\text { Year } \\
(Y)\end{array}$} \\
\hline 2017 & & 180.2 & $20.1 \mathrm{~b}$ & $67.4 \mathrm{~b}$ & $3387 \mathrm{~b}$ & $41.0 \mathrm{~b}$ & $1377 \mathrm{~b}$ & $12.5 \mathrm{a}$ \\
\hline 2018 & & 182.5 & $20.8 \mathrm{a}$ & $71.7 \mathrm{a}$ & 3898 a & $48.2 \mathrm{a}$ & $1878 \mathrm{a}$ & $10.5 \mathrm{~b}$ \\
\hline \multicolumn{9}{|c|}{$\begin{array}{c}\text { Fertilizer Applications } \\
(\text { FA })\end{array}$} \\
\hline Nitrogen $(\mathbf{N})$ & & $198.0 \mathrm{a}$ & $21.6 \mathrm{ab}$ & $76.4 \mathrm{a}$ & $3821 \mathrm{de}$ & $43.8 \mathrm{~cd}$ & $1681 \mathrm{c}$ & $12.2 \mathrm{ab}$ \\
\hline Phosphorus (P) & & $174.3 \mathrm{ef}$ & $19.5 \mathrm{~cd}$ & $63.6 \mathrm{e}$ & $3266 \mathrm{fg}$ & $42.4 \mathrm{e}$ & 1386 de & $10.2 \mathrm{c}$ \\
\hline Vermicompost (V) & & $184.6 \mathrm{bc}$ & $18.7 \mathrm{~d}$ & $63.1 \mathrm{ef}$ & $2748 \mathrm{~h}$ & $46.8 \mathrm{a}$ & $1292 \mathrm{e}$ & $11.2 \mathrm{ac}$ \\
\hline Leonardite (L) & & $173.4 \mathrm{ef}$ & $19.3 \mathrm{~cd}$ & $61.4 \mathrm{f}$ & $2817 \mathrm{~h}$ & $45.0 \mathrm{bc}$ & $1274 \mathrm{e}$ & $12.3 \mathrm{ab}$ \\
\hline NV & & $181.5 \mathrm{~cd}$ & $22.8 \mathrm{a}$ & $76.4 .3 \mathrm{a}$ & $4854 \mathrm{a}$ & $43.3 \mathrm{de}$ & $2114 \mathrm{a}$ & $10.5 \mathrm{bc}$ \\
\hline NP & & 175.0 ef & $21.5 \mathrm{ab}$ & $74.7 \mathrm{a}$ & $4233 \mathrm{bc}$ & $43.4 \mathrm{de}$ & $1933 \mathrm{~b}$ & $11.9 \mathrm{ac}$ \\
\hline NL & & $188.1 \mathrm{~b}$ & $21.7 \mathrm{ab}$ & $75.3 \mathrm{a}$ & $4439 \mathrm{~b}$ & $43.2 \mathrm{de}$ & $1836 \mathrm{~b}$ & $13.0 \mathrm{a}$ \\
\hline PV & & $184.3 \mathrm{bc}$ & $21.1 \mathrm{~b}$ & $72.9 \mathrm{~b}$ & $3985 \mathrm{~cd}$ & $46.2 \mathrm{ab}$ & $1841 \mathrm{~b}$ & $12.9 \mathrm{a}$ \\
\hline PL & & $187.6 \mathrm{~b}$ & $19.5 \mathrm{~cd}$ & $66.9 \mathrm{~d}$ & $3265 \mathrm{fg}$ & $45.4 \mathrm{~b}$ & $1487 \mathrm{~d}$ & $11.5 \mathrm{ac}$ \\
\hline $\mathbf{V L}$ & & $177.3 \mathrm{de}$ & $20.6 \mathrm{bc}$ & $69.0 \mathrm{c}$ & 3584 ef & $45.8 \mathrm{ab}$ & $1647 \mathrm{c}$ & $10.3 \mathrm{c}$ \\
\hline Control (C) & & $170.7 \mathrm{f}$ & $18.9 \mathrm{~d}$ & $65.7 \mathrm{~d}$ & $3058 \mathrm{gh}$ & $45.6 \mathrm{ab}$ & $1410 \mathrm{de}$ & $10.6 \mathrm{bc}$ \\
\hline Mean & & 181.4 & 20.5 & 69.6 & 3643 & 44.6 & 1628 & 11.5 \\
\hline Source of variation & d.f & & & & & & & \\
\hline Year $(\mathbf{N})$ & 1 & $7.731 *$ & $29.089 * *$ & $181.369 * *$ & $15.219 *$ & $1628.4 * *$ & $63.059 * *$ & $29.19 * *$ \\
\hline $\begin{array}{l}\text { Fertilizer } \\
\text { Applications (FA) }\end{array}$ & 10 & $19.90 * *$ & $8.226 * *$ & $83.442 * *$ & $34.819 * *$ & $10.733 * *$ & $27.105 * *$ & $2.483^{*}$ \\
\hline NxFA & 10 & $2.226^{*}$ & $0.332^{\mathrm{ns}}$ & $1.773^{\mathrm{ns}}$ & $1.034^{\mathrm{ns}}$ & $15.856^{* *}$ & $1.171^{\mathrm{ns}}$ & $2.250 *$ \\
\hline Error & 30 & $1.814^{\mathrm{ns}}$ & $0.197^{\mathrm{ns}}$ & $0.717^{\mathrm{ns}}$ & $3.493^{\mathrm{ns}}$ & $0.445^{\mathrm{ns}}$ & $3.772^{\mathrm{ns}}$ & $0.823^{\mathrm{ns}}$ \\
\hline
\end{tabular}

*, ** significant at the level of 0.05 and 0.01 , respectively. For each main effect, values within the columns followed by the same letter are not significant., ns, nonsignificant.

The fertilizers and their combinations, except vermicompost alone, increased the head diameter compared to the control. The head diameter decreased by $1.3 \%$ on average in the plots treated with vermicompost alone, and increased by $20.3 \%$ on average in the plots treated with nitrogen vermicompost (NV).

Although the head diameter was found to be the lowest $(18.7 \mathrm{~cm})$ in the application of vermicompost alone, it was found to be the highest $(22.8 \mathrm{~cm})$ in the application of vermicompost in combination with nitrogen fertilizer (NV). On the other hand, in the applications of NL, N, and $\mathrm{NP}$, the head diameters were found to be $21.8,21.6$, and $21.8 \mathrm{~cm}$, respectively. The significant difference in the vegetative parameters could be explained by the availability of adequate moisture, which enables roots to absorb enough nutrients for plant growth (Lawal et al., 2011). Similar results were reported in different studies in which the head diameters were found to vary between 15.9 and $22.3 \mathrm{~cm}$ in sunflower (Ozer et al., 2003; Sefaoglu, 2019). On the other hand, Gunay (2014) reported that application of organomineral fertilizers increased not only the yield and quality parameters of sunflower but also the contents of nitrogen, phosphorus, and potassium, which are essential plant nutrients.

\section{Thousand grain weight}

1000-Grain weight is commonly used as a major determinant of sunflower yield because a positive correlation exists between grain weight and yield. The fuller and larger seeds have a higher 1000-grain weight, and as a result, have a higher yield. In this study, 1000-grain weight significantly differed between 2017 and 2018. Seed weight differed depending on various growing seasons and conditions. Due to the fact that in 2017, in the first week of August, the flowering period of the plant, there was almost no rainfall and the temperature was high; the 1000-grain weight was found to be lower in $2017(67.4 \mathrm{~g})$ than in 2018 (71.7 g) (Figure 1 and Table 1). Beyyavas et al. (2011) reported that genotype and ecological conditions are two important factors affecting 1000-grain weight. In the present study, fertilizer applications had a significant effect on grain weight. It was found that using fertilizers with low protein values in combination with nitrogen increased the 1000-grain weight. The highest 1000-grain weight was obtained from the application of nitrogen (N) alone, followed by other applications where nitrogen was used in a combination (NL, NV, and NP) (76.4, 76.2, 75.3, and 74.7 $\mathrm{g}$, respectively). On the other hand, the lowest 1000-grain weight was obtained from the application of Leonardite alone, followed by Vermicompost alone and Phosphorus 
alone $(61.4,63.1$, and $63.6 \mathrm{~g}$, respectively). The reason why the 1000-grain weight tended to increase in the application of nitrogen alone and the applications of nitrogen in a combination can be explained by the fact that nitrogen is the most common nutrient element in the structure of the seed and it has an active function in the seed. Ebrahim et al. (2003) and Nobre et al. (2014) reported that application of nitrogen fertilizers caused a significant increase in the 1000-grain weight of sunflower. Similar to the results of the present study, Soleymani et al. (2016) reported that the highest 1000-grain weight was obtained from the application of chemical fertilizers in combination with vermicompost in sunflowers.

\section{Seed yield}

Seed yield is mostly a result of the cumulative effects of various yield components under the influence of environmental conditions and different agricultural practices such as fertilization. So, the seed yield is controlled by several internal and external factors. In this study, the mean seed yield was found to be $3380.7 \mathrm{~kg} \mathrm{ha}^{-1}$ in 2017 and $3890.8 \mathrm{~kg} \mathrm{ha}^{-1}$ in 2018. The seed yield in the second year of the experiment was about $510 \mathrm{~kg} \mathrm{ha}^{-1}$ more than that in the first year. This difference may be due to the fact that the total amount of precipitation during the growth period was much higher in 2018 (285.9 mm) than in 2017 (94 mm). Using organic and inorganic fertilizers alone decreased the seed yield. Although one of the lowest seed yields was obtained from the control application with 3058 $\mathrm{kg} \mathrm{ha}{ }^{-1}$, the lowest grain yield was obtained from the application of vermicompost with $2748 \mathrm{~kg} \mathrm{ha}^{-1}$, followed by the application of leonardite with $2817 \mathrm{~kg} \mathrm{ha}^{-1}$. On the other hand, the highest seed yield was obtained from the applications of these fertilizers in combination with nitrogen, that is, 4854.0 and $4439.0 \mathrm{~kg} \mathrm{ha}^{-1}$ from the applications of NV and NL, respectively (Figure 2). The seed yield increased in the applications involving nitrogen fertilizer, one of the inorganic fertilizers. This increase may be due to the positive effects of this nutrient and its combinations on the yield elements such as head diameter and 1000-grain weight (Table 1). The most important reason for the positive response of the sunflower to these fertilizers may be the fact that the soil was poor in nitrogen due to organic matter (Table 1). It has been reported that organic fertilizer applications are made useful by adding sufficient amount of nitrogen fertilizers (Bayite Kasule, 2009), and these fertilizers increase the amount of nitrogen in the soil and support the growth of plants, resulting in higher yields (Nogales et al., 2005). Amjed et al. (2012) reported that nitrogen increased the seed yield in sunflower. In various studies (Baishya, 2009; Zaman et al., 2011), it was emphasized that organic fertilizers increased the yield by enhancing the availability of $\mathrm{N}, \mathrm{P}$, and $\mathrm{K}$ in the soil. Similar to the results of the present study, previous studies on sunflower and potato reported that high yields were obtained from the mixed application of organic and inorganic fertilizers (especially nitrogen) (Ghalavand et al., 2011; Esmaelian et al., 2012; Yeng et al., 2012; Asghari et al., 2015; Sikder et al., 2017) Again similarly, it was reported that the yield increased (Kmet'ová et al., 2013; Yourtchi et al., 2013; Javaad and Panwar, 2013) and the highest grain yield was obtained in the combined use of inorganic fertilizers and vermicompost in sunflower (Khodaei-Joghan et al., 2018).

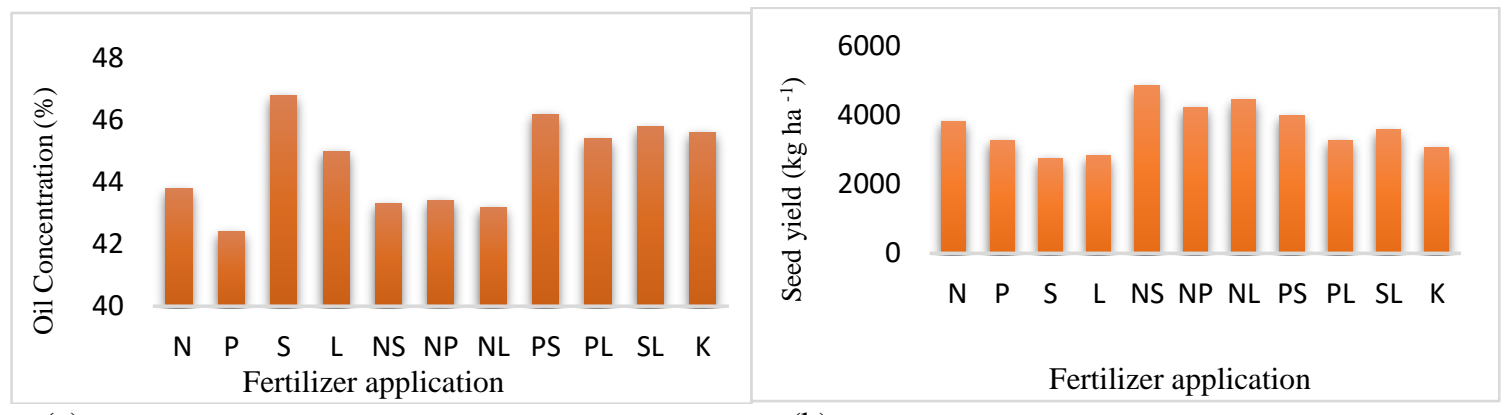

(a)

(b)

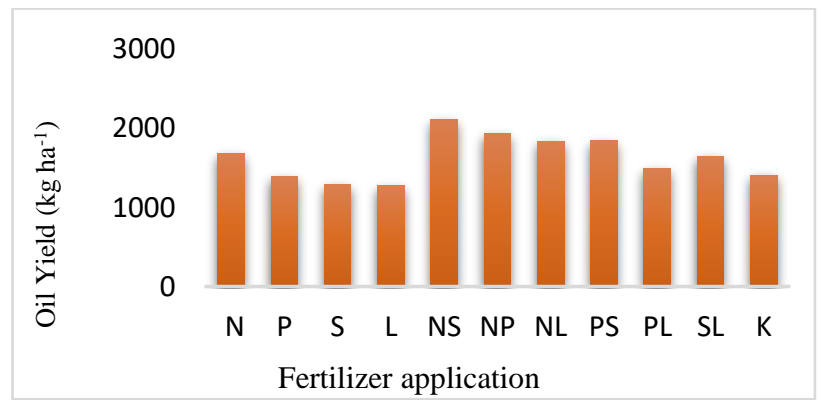

(c)

Figure 2: The seed yield (a), oil content (b), and oil yield (c) of the oil sunflowers produced by applying different organic and inorganic fertilizers 


\section{Oil content}

The seed oil concentration was significantly affected by years and fertilizer applications. The oil content was higher $(48.2 \%)$ in the second year than in the first year $(41.0 \%)$ (Table 1). The reduced oil content was probably caused by the very low total annual rainfall. Water stress during the vegetative stage as well as the reproductive growth periods decreased the seed oil content. Previous studies reported that the oil content was significantly affected by the temperature differences over the years, and the oil content decreased in the years when the weather was hot during the grain filling period (Weiss, 1983; Roche et al., 2004). In the present study, the inorganic and organic fertilizations, or their combinations caused differences in the seed oil concentration of sunflower. Compared to the control, the oil content decreased in all the applications except the following applications: vermicompost alone (V), leonardite alone (L), vermicompost and leonardite (VL), and phosphorus and vermicompost (PV). The highest oil concentration $(46.8 \%)$ was detected in the application of vermicompost alone, followed by L (46.2\%), PV (45.0\%), and VL (45.8\%). The lowest oil content was detected in NL (43.2\%), followed by NV (43.3\%), NP (43.4\%), and N $(43.8 \%)$. The application of nitrogen alone and in combination with organic fertilizers decreased the seed oil content (Figure 2). Similarly, it was reported in previous studies that nitrogen application decreased the seed oil content (Ghalavand et al., 2011), and organic nutrient sources increased the oil content and yielded the highest seed oil content (Ghalavand et al., 2011; Kinama et al., 2018). In the present study, the application of vermicompost increased the oil content in sunflower. Previous studies reported that this is due to, on the one hand, the slow availability of nitrogen and other nutrients in vermicompost, and on the other hand, the fact that organic fertilizers improve the physical properties of the soil, which increases the plant growth, photosynthesis, and ultimately oil synthesis (Rasool et al., 2013; KhodaeJoghan et al., 2018).

\section{Oil yield}

Oil yield is economically the most important yield criterion in oil crops. The oil yield obtained from sunflower plants in this study substantially differed by years and fertilizer applications (Table 1). The oil yield was higher in $2018\left(1878 \mathrm{~kg} \mathrm{ha}^{-1}\right)$ than in 2017 (1377 $\left.\mathrm{kg} \mathrm{ha}^{-1}\right)$. The difference between the mean oil yields in 2017 and 2018 might be associated with the reduction in oil content and the increase in total seed yield (Table 1). Likewise, the case for the grain yield, the oil yield increased in the applications involving nitrogen fertilizers, one of the inorganic fertilizers. The oil yield varied between 2144 and $1274 \mathrm{~kg}$ $\mathrm{ha}^{-1}$ depending on the fertilizer applications. The lowest oil yield was found to be in the application of Leonardite (L) alone with $1274 \mathrm{~kg} \mathrm{ha}^{-1}$, followed by vermicompost (V) alone, phosphorus (P), and the control with 1292, 1386, and $1410 \mathrm{~kg} \mathrm{ha}^{-1}$, respectively. The highest oil yield was found to be in the application of nitrogen and vermicompost (NV) with $2114 \mathrm{~kg} \mathrm{ha}^{-1}$, followed by the application of nitrogen and phosphorus (NP) with $1933 \mathrm{~kg} \mathrm{ha}^{-1}$ (Table 1).
Vermicompost had a low oil yield when applied alone; however, it had the highest oil yield when combined with nitrogen (NV) (Figure 2). Oil yield, a combination of grain yield and oil content, may also be affected by all growth conditions and ecological factors that affect the grain yield and oil content. Amjed et al. (2012) reported that nitrogen had a positive effect on the oil yield in sunflower, as it increased the grain yield. Similar to the results in the literature, in the present study, the use of vermicompost in combination with nitrogen increased the oil yield.

\section{Protein content}

The protein content of seeds shows their quality and nutritional value. The applications of organic and inorganic fertilizers or their combinations decreased the seed protein contents of the sunflowers in 2018. The differences in protein contents of sunflowers depending on the fertilizer applications were higher in 2017 (12.5\%) than in 2018 $(10.5 \%)$. Protein content, a quality criterion in oil crops, is affected by the environmental factors such as temperature and precipitation as well as the genetic characteristics of the variety. In this study, the seed protein contents were found to differ depending on the organic and inorganic fertilizers or their combinations. Except for the applications of phosphorus alone $(\mathrm{P})$, vermicompost and nitrogen (NV), and vermicompost and leonardite (VL), all the applications increased the protein content compared to the control. Moreover, the lowest protein content was found to be in $\mathrm{P}$ with $10.2 \%$, followed by VL (10.3\%) and NV (10.5\%). On the other hand, the highest protein content was found to be in NL (13.0\%), followed by PV (12.9\%).

\section{CONCLUSIONS}

Sunflower is sensitive to fertilization, so various forms of organic and inorganic fertilizer were studied to maximize the yield and quality of sunflower. The results of the study were in agreement with other studies indicating the effects of organic and inorganic fertilizers, or their combination on yield and agronomic characteristics. The yield, yield components, and quality of oilseed sunflower generally tended to increase with the use of organic and inorganic combinations. Therefore, it is important to make the right decision in choosing the fertilizer combinations. The effect of organic and inorganic fertilizers, or their combinations on the seed yield, yield components, and quality of sunflower was found to be significant in 2017 and 2018. The highest seed yield (4854 $\left.\mathrm{kg} \mathrm{ha}^{-1}\right)$ and oil yield (2114 kg ha-1) were obtained from the combined use of nitrogen and vermicompost. Moreover, the use of vermicompost alone yielded the highest oil content $(46.8 \%)$. According to the results of this study, combined applications of organic (vermicompost) and inorganic (nitrogen) fertilizers had the highest yield and agronomic characteristics in oilseed sunflower production; so, these applications can be recommended for the similar ecological conditions, that is, short growing season and high altitude.

\section{ACKNOWLEDGEMENT}

This study was supported by Ataturk University [Project BAP No. FBA/ 2018/6730] 


\section{LITERATURE CITED}

Akbari, P., A. Ghavaland, A.M. Modares Sanavy, M. Aghaalikhani and K. Shoghi, Alkhoran. 2011. Comparison of different nutritional levels and effect of plant growth promoting rhizobacteria (PGPR) on the grain yield and quality of sunflower. Australian Journal of Crop Science 5(12):15701576

Amjed, A. and U. Sami. 2012. Effect of nitrogen on achene protein, oil, fatty acid profile, and yield of sunflower hybrids. Chilean Journal of Agricultural Research 72(4).

Asghari, T. and A.F.R. Mir. 2015. Farmyard manure application of potato (Solanum tuberosum var. Agria) with tree level of nitrogen fertilizer. 2015 International Journal of Farming and Allied Sciences 2015-4-6/536-540/ 30 June, 2015 ISSN 23224134.

Atiyeh, R., C. Edwards, S. Subtler and J. Metzger. 2000. Effect of vermicomposts and composts on plant growth in horticultural container media and soil. Pedo Biologia. 44: 579- 590.

Azarmi, R., M.T. Giglou and R.D. Taleshmikail. 2008. Influence of vermicompost on soil chemical and physical properties in tomato (Lycopersicum esculentum) field. African Journal of Biotechnology 7(14): 2397-2401

Baishya, L.K. 2009. Response of potato varieties to organic and inorganic sources of nutrients, Ph.D. Thesis. Visva-Bharati University, West Bengal, India, pp. 99-102.

Bayite-Kasule, S. 2009. Inorganic fertilizer in Uganda: Knowledge gaps, profitability, subsidy, and implications of a national policy. International Food Policy Research Institute (IFPRI). Brief No:8

Beyyavas, V., H. Haliloglu, O. Copur and A. Yilmaz. 2011. Determination of seed yield and yield components of some safflower (Carthamus tinctorius L.) cultivars, lines and populations under the semi-arid conditions. African Journal of Biotechnology 10 (4): 527-534

Buriro, M., M.N. Rais, A.W. Solangi, A. Soomro, A.W. Gandahi and S. Kashani. 2015.Impact of organic and inorganic manures on sunflower yield and yield components. Science International-.Lahore. 27(4): 3267-3270

Day, S. and O. Kolsarici. 2014. Effect of different row spacings and nitrogen doses on yield and yield components in hybrid snack sunflower (Helianthus annuus L.) genotype in Ankara conditions. Soil Water Journal 3 (2): 81-89.

Ebrahim, L. E., E.A. El Absawy, A.H. Salem and N.A. Gaaffar. 2003 Effects of nitrogen and phosphorus fertilization levels on growth, photosynthetic pigments, yield and yield components of sunflower (Helianthus annuus L.) Zagazig Journal of Agricultural Research 30: 1223-1271.

Esmaelian, Y., A.R. Sirousmehr, M.R. Asghripour and E. Amiri. 2012. Comparison of sole and combined nutrient application on yield and biochemical composition of sunflower under water stress. International Journal of Applied Science and Technology. Vol. 2 No. 3

Flagella, Z., T. Rotunno, E. Tarantino, R. Caterina, A. Caro, R. Di Caterina, A. Di Caterina and A. De Caro. 2002. Changes in seed yield and oil fatty acid composition of high oleic sunflower (Helianthus annuus L.) hybrids in relation to the sowing date and the water regime. European Journal of Agronomy 17: 221-230.

Ghamry, AM., A.A El-Hamid and A.A Mosa. 2009. Effect of farmyard manure and foliar application of micronutrients on yield characteristics of wheat grown on salt affected soil. American-Eurasian Journal Agriculture Environment Sciences 5(4): 460-465.

Gorttappeh, A.H., A. Ghalavand, M.R. Ahmady and S.K. Mirnia. 2000. Effect of organic,inorganic and integrated fertilizers on quantitative and qualitative traits of different cultivars of sunflower (Helianthus annuus L.) in western Azarbaijan. Iran. Journal of Agricultural Sciences 6(2): 85-104

Gunay, A. 2014. Effects of Organomineral Fertilizer Applications on Yield and Quality Parameters of Sunflower. Master Thesis. Ege University, Institute of Science, Soil Science and Plant Nutrition Department. Izmir

Hussain, S.S. and T. Thomas. 2010. Effect of nitrogen and sulphur on yield, mineral accumulation and protein content of sunflower (Helianthus annuus L.) in inceptisol. Research Journal of Agricultural Sciences 1(2): 89-92.

Javaad, S. and A. Panwar. 2013. Effect of biofertilizer, vermicompost and chemical fertilizer on different biochemical parameters of Glycine max and Vigna mungo. Recent Research in Science and Technology 5(1): 40-44.

Khodae1-Joghan, A., M. Gholamhoseın1, A.A. Majid, F. Habibzadeh, A. Sorooshzadeh and A. Ghalavand. 2018. Response of sunflower to organic and chemical fertilizers in different drought stress conditions. Acta agriculturae Slovenica 111(2): 271-284.

Kimana, J.M., M. Irika and H. M. Jean Pierre. 2018. Influence of inorganic and organic nitrogen fertilizers regimes on oil content of sunflower in Morogoro, Tanzania, International Journal of Agronomy and Agricultural Research 166-174

Kmet'ová, M., P. Kováčik and M. Renčo. 2013. The effect of different doses application of dry granulated vermicompost on yield parameters of maize and potatoes. Nitra, Slovaca Universitas Agriculturae Nitriae 8-14

Lawal, B.A., G.O. Obigbesan, W.B. Akanbi and G.O. Kolawole. 2011. Effect of planting time on sunflower (Helianthus annuus L.) Productivity in Ibadan 6 (13): 3049-3054.

Makinde, E.A., L.S. Ayeni, S.O Ojeniyi and J.N. Odedina. 2010. Effect of organic, organomineral and NPK fertilizer on nutritional quality of amaranthus in Lagos, Nigeria Researcher 2(12): 32-36.

Montemurro, F., D. De Giorgio, F. Fornaro, E. Scalcione and C. Vitti. 2007. Influence of climatic conditions on yields, $n$ uptake and efficiency in sunflower, Italian Journal of Agrometeorology 2: 28-34.

Nobre, G.R., D.W. Da Sousa, G.S. De Lima, H.R. Gheyi, A.S. Dias and P.W.A. Pinheiro. 2014. Sources and doses of nitrogen in the production of sunflower plants irrigated with saline water. Brasilia, Revista Brasileira de Engenharia Agricola e Ambienta vol.18.

Nogales, R., C. Cifuentes and E. Benitez. 2005. Vermicomposting of winery wastes: a laboratory study. Journal of Environmental Science and Health Part B 40(4): 659-673.

Olaniyi, J.O., W.B. Akanbi, O.A. Olaniran, and O.T. Ilupeju. 2010. The effect of organo-mineral and inorganic fertilizers on the growth, fruit yield, quality and chemical compositions of okra. Journal of Animal and Plant Sciences 9 (1): 11351140.

Ozer, H., E. Ozturk and T. Polat. 2003. Determination of argonomic performances of some oil sunflower hybrids grown in Erzurum ecological conditions Turkish Journal of Agriculture and Forestry 27: 199-205.

Rasool, F., B. Hassan, I.A. Jahangir, T. Ali and T. Mubarak. 2013. Nutriotional yield and economic responses of sunflower to integrated levels of nitrogen, sulphur and farm yard manure. University of Agricultural Sciences and Technology of Kashmir, India. 191-121.

Reddy G.K.M., K.S. Dangi, S.S. Kumar and A.V. Reddy. 2003. Effect of moisture stress on seed yield and quality in sunflower (Helianthus annuus L.). Journal of Oilseed Research 20: 282-283.

Roche, J., A. Essahat, M. Bouniols, Z. El-Asri, M. Mouloungui, M. Mondies, Alghoum. 2004. Diversified composition of 
sunflower (Helianthus annuus L.). Journal of Eco. Physiology. 3: 59-71

Sefaoglu, F. 2019. Determination of adaptation capabilities of some oil sunflower genotypes in Igdir wet conditions. Journal of Igdır University Institute of Science 9(3): 1747-1753.

Seghatoleslami, M. J., R. Bradaran, E. Ansarinia, and S. G. Mousavi. 2012. Effect of irrigation and nitrogen level on yield, yield components and some morphological traits of sunflower. Pakistan Journal Botaniy. 44(5): 1551-1555.

Sharma, K.L., K. Neelaveni, J.C. Katyal, A. Srinivasa Raju, K. Srinivas and J. Kusuma Grace. 2008. Effect of combined use of organic and inorganic sources of nutrients ons yield, soil fertility, and overall soil quality in rainfed alfisol. Communications in Soil Science and Plant Analysis 39:11-12: 1791-1831,

Sikder, R.K., M.M. Rahman, S.M. Washim Bari and H. Mehraj. 2017. Effect of organic fertilizers on the performance of seed potato. Tropical Plant Research 104-108,

Singh, B.K., K.A. Pathak, A.K. Verma, V.K. Verma and B.C. Deka, 2011. Effects of vermicompost, fertilizer and mulch on plant growth, nodulation and pod yield of French bean (Phaseolus vulgaris L.). Vegetable Crops Research Bulletin, 74(1): 153-165.

Soleymani F., G. Ahmadvand and A.A. Safarı Sanjanı. 2016. The effect of chemical, biological and organic nutritional treatments on sunflower s yield and yield components under the influence of water deficit stress. Journal Agroecology 8 (1): 107-119.

Steel, R.G.D. and J.H. Torrie. 1980. Principles and procedures of statistics. McGraw-Hill Book Company, Inc., New York, Toronto, London. 1960 pp.xvi + 481 p.
Uslu, N., I. Tutluer, Y. Taner, B. Kunter, Z. Sagel and H. Peskircioglu. 2002. Effects of temperature and drought stress during elongation and branching on development and yield of safflower. Sesame and Safflower Newsletter No: 17, 101-106.

Wabekwa, J.W., M.M. Degri and L.C. Dangari. 2012. The effects of nitrogen mineral on yield performance of sunflower in Bauchi State. Nigeria J. Envir. Iss. Agric. In Devel. Count. 4(3): 56- 61

Waclawowiez, R., D. Parylak and W. Wojciechowski. 2006. Formation of selected properties of the soil in the third year after applying of organic fertilization. Frogmenta Agronomica 28 (2): 206-215.

Weiss, E.A. 1983. Safflower: In: Oilseed Crops, Tropical Agriculture Series, Longman Inc., Leonord Hill Books, New York, USA.

Yeng, S.B., K. Agyarko, H.K. Dapaah., W.J. Adomako and E. Asare. 2012. Growth and yield of sweet potato (Ipomoea batatas L.) as influenced by integrated application of chicken manure and inorganic fertilizer. African Journal of Agricultural Research 7(39): 5387-5395.

Yourtchi, M.S., M.H.S. Hadi and M.T. Darzi. 2013. Effect of nitrogen fertilizer and vermicompost on vegetative growth, yield and NPK uptake by tuber of potato (Agriacv.). Int. J. Agric. Crop Sci. 5 (18): 2033-2040.

Zaman, A., A. Sarkar, S. Sarkar and W.P. Devi. 2011. Effect of organic and inorganic sources of nutrients on productivity, specific gravity and processing quality of potato (Solanum tuberosum). Indian Journal of Agricultural Sciences 81(12): $1137-1142$ 